\title{
Community structure of arboreal and soil-dwelling arthropods in three different rice planting indexes in freshwater swamps of South Sumatra, Indonesia
}

\author{
TILI KARENINA ${ }^{1,2,}$, SITI HERLINDA ${ }^{3,4}$, CHANDRA IRSAN ${ }^{3,4}$, YULIA PUJIASTUTI $^{3,4}$, HASBI $^{4,5}$, \\ SUPARMAN ${ }^{3}$, BENYAMIN LAKITAN ${ }^{4,6}$, HARMAN HAMIDSON ${ }^{3}$, ABU UMAYAH $^{3}$ \\ ${ }^{1}$ Graduate Program of Agricultural Sciences, Faculty of Agriculture, Universitas Sriwijaya. Jl. Padang Selasa No. 524, Bukit Besar, Palembang 30139, \\ South Sumatra, Indonesia \\ ${ }^{2}$ Research and Development Agency of South Sumatera Province. Jl. Lorok Pakjo, Palembang 30136, South Sumatra, Indonesia \\ ${ }^{3}$ Department of Plant Pests and Diseases, Faculty of Agriculture, Universitas Sriwijaya. Jl. Raya Palembang-Prabumulih Km 32, Indralaya, Ogan Ilir \\ 30662, South Sumatra, Indonesia. Tel.: +62-711-580663, Fax.: +62-711-580276, "email: sitiherlinda@unsri.ac.id, \\ ${ }^{4}$ Research Center for Sub-optimal Lands, Universitas Sriwijaya. J1. Padang Selasa No. 524, Bukit Besar, Palembang 30139, South Sumatra, Indonesia \\ ${ }_{5}^{5}$ Department of Agricultural Engineering, Faculty of Agriculture, Universitas Sriwijaya. Jl. Raya Palembang-Prabumulih Km 32, Indralaya, Ogan Ilir \\ 30662, South Sumatra, Indonesia \\ ${ }^{6}$ Department of Agronomy, Faculty of Agriculture, Universitas Sriwijaya. Jl. Raya Palembang-Prabumulih Km 32, Indralaya, Ogan Ilir 30662, South \\ Sumatra, Indonesia
}

Manuscript received: 20 August 2020. Revision accepted: 26 September 2020

\begin{abstract}
Karenina T, Herlinda S, Irsan C, Pujiastuti Y, Hasbi, Suparman, Lakitan B, Hamidson H, Umayah A. 2020. Community structure of arboreal and soil-dwelling arthropods in three different rice planting indexes in freshwater swamps of South Sumatra, Indonesia. Biodiversitas 21: 4839-4849. Differences in the index of rice planting can cause differences in the structure of the arthropod community. This study aimed to characterize the community structure of the arboreal and soil-dwelling arthropods in the three different rice planting indexes (PI) in the freshwater swamps of South Sumatra. Sampling of the arthropods using D-vac and pitfall traps was conducted in the three different rice planting, namely one (PI-100), two (PI-200), and three (PI-300) planting indexes of the rice. The results of the study showed that the dominant predatory arthropod species in the rice fields were Pardosa pseudoannulata, Tetragnatha javana, Tetragnatha virescens, Pheropsophus occipitalis, Paederus fuscipes, and the dominant herbivorous insects were Leptocorisa acuta, Nilavarpata lugens, and Sogatella furcifera. The abundance of arboreal predatory arthropods was the highest in the PI-300 rice and the lowest in the PI-100 rice. The abundance of soil-dwelling arthropods was the highest in the rice PI-100, and low in the rice PI200 and PI-300, but the rice PI-100 had the highest abundance of the herbivorous insects. The rice PI-300 was the most ideal habitats to maintain the abundance and the species diversity of the arboreal predatory arthropods. Thus, the rice cultivation throughout the year was profitable in conserving and maintaining the abundance and species diversity of the predatory arthropods.
\end{abstract}

Keywords: Chironomus, Copidosoma, Micraspis lineata, Orseolia oryzae, Pheropsophus occipitalis

\section{INTRODUCTION}

Freshwater swamps are wetlands inundated by water from rivers or rain throughout the year (Hanif et al. 2020). Freshwater swamps are generally submerged in the rainy season and drought in the dry season (Karenina et al. 2020). The most extensive freshwater swamps in Indonesia are in Sumatra (11.9 Mha) (Margono et al. 2014) centered in South Sumatra. The typical characteristic of freshwater swamps is that it has three types of land, namely shallowly, moderately, and deeply flooded swamps (Lakitan et al. 2019). The different types of freshwater swamps result in differences in rice management (Karenina et al. 2020). In the shallowly and moderately flooded swamps, farmers generally plant rice more than once a year, while in the deeply flooded swamps it is generally planted once a year (Lakitan et al. 2019). The total frequency or the number of rice planting times a year is termed the rice planting index (PI) (Kawanishi and Mimura 2013). The results of our observations in Ogan Ilir District, South Sumatra from
2018 until now, show that the two rice planting indexes (PI-200) up to three rice planting indexes (PI-300) a year have tended to be carried out by farmers who have capital. or rice estate, while the smallholder farmers still plant rice once a year (one rice planting index or PI-100) so that from October to the end of the rainy season, the smallholder farmers do not utilize their rice fields.

The differences in the index of rice planting can cause differences in the structure of the arthropod community that inhabit the agroecosystem (Dominik et al. 2017). The method of planting broadcast seeding and transplanting rice can also affect the arthropod community (Herlinda et al. 2019; Lisha et al. 2020; Rahman et al. 2020). Intensive insecticide spraying has proved to decrease the abundance of predatory arthropods (Hanif et al. 2020). Broadspectrum insecticides are commonly sprayed in rice ecosystems, for example, abamectin (Dionisio and Rath 2016) not only significantly reduces the population of insect pests but also the population of predatory arthropods, parasitoids, and neutral insects (Herlinda et al. 2020b). 
The rice fields planted throughout the year can provide habitats and niches for arthropods throughout the year (Prabawati et al. 2019) so that the presence of arthropods in the rice fields throughout the year can cause stability in the rice ecosystem (Masika et al. 2017; Prabawati et al. 2019). The stable rice ecosystems are characterized by the maximum performance of the processes in the food and web chain (Settle et al. 1996). This stable ecosystem process is due to the trophic interaction between ecosystem components (Wood et al. 2015), namely there are host plants and herbivorous insects, then herbivores are preyed on by predators or parasitized by parasitoids, while parasitoids or predators are parasitized or preyed on by the trophic level above it (Settle et al. 1996). The breaking of food web composition can lead to the domination of one trophic level (Kardol and Long 2019). For example, the absence of the generalist predator in the rice ecosystem leads to outbreaks of the brown planthopper (BPH) (Daravath and Chander 2017). This study aimed to characterize the community structure of the arboreal and soil-dwelling arthropods in the three different rice planting indexes in the freshwater swamps of South Sumatra.

\section{MATERIALS AND METHODS}

\section{Study area}

The survey was conducted from April to August 2019 on the three types of rice fields (Figure 1) that differ in their management (Table 1). The first expanse of up to \pm 800 ha was located in "Pelabuhan Dalam" Village, Pemulutan Subdistrict, Ogan Ilir District, South Sumatra, where the local farmers generally planted rice once a year (PI-100), their method of planting rice was still transplanting, and did not apply synthetic pesticides. The second expanse of \pm 300 ha was located in "Simpang Pelabuhan Dalam" Village, Pemulutan Subdistrict, Ogan
Ilir District, South Sumatra, where the modern farmers generally plant rice twice a year (PI-200), the planting method was the broadcast seeding, applied synthetic pesticides (2-3 times a season), pumped, and applied synthetic fertilizers. The third expanse of \pm 200 ha was located in Pedu Village, Jejawi Subdistrict, Ogan Komering Ilir (OKI) District, South Sumatra Province, where the local farmers planted rice three times (PI-300) a year, the planting method was the broadcast seeding, applied synthetic pesticides (2-3 times a season), pumped, and used synthetic fertilizers.

\section{Observation of arboreal arthropods}

The arboreal arthropods were sampled every two weeks starting from the rice aged 14 to 84 days after transplanting (DAT) or broadcast seeding, and the sampling was carried out at 06.00-07.00 am. Each land type (PI-100, PI-200, and PI-300) was taken from each sample area consisting of three plots, each measuring \pm 1 ha per plot, and each plot divided into four subplots spread over four corner land. The sampling for each subplot was carried out using a plastic cover (size $30 \times 30 \times 70 \mathrm{~cm}^{3}$ ). A hood was placed in each subplot to trap the arthropods. The arthropod sampling used the D-vac followed the method of Herlinda et al. (2019b). The suction of the arthropods was carried out on all arthropods trapped in the hood and the canopy and rice stalks. The suction was carried out for \pm 5 minutes for each subplot. All collected arthropods were transferred to $10 \mathrm{~mL}$ volume vials containing $96 \%$ ethanol and labeled for further identification in the Entomology Laboratory of the Department of Plant Pests and Diseases, Faculty of Agriculture, Universitas Sriwijaya for identification. The identification of spiders used the reference of Whyte and Anderson (2017), and the identification of insects used the reference books of Heinrichs et al. (2016).

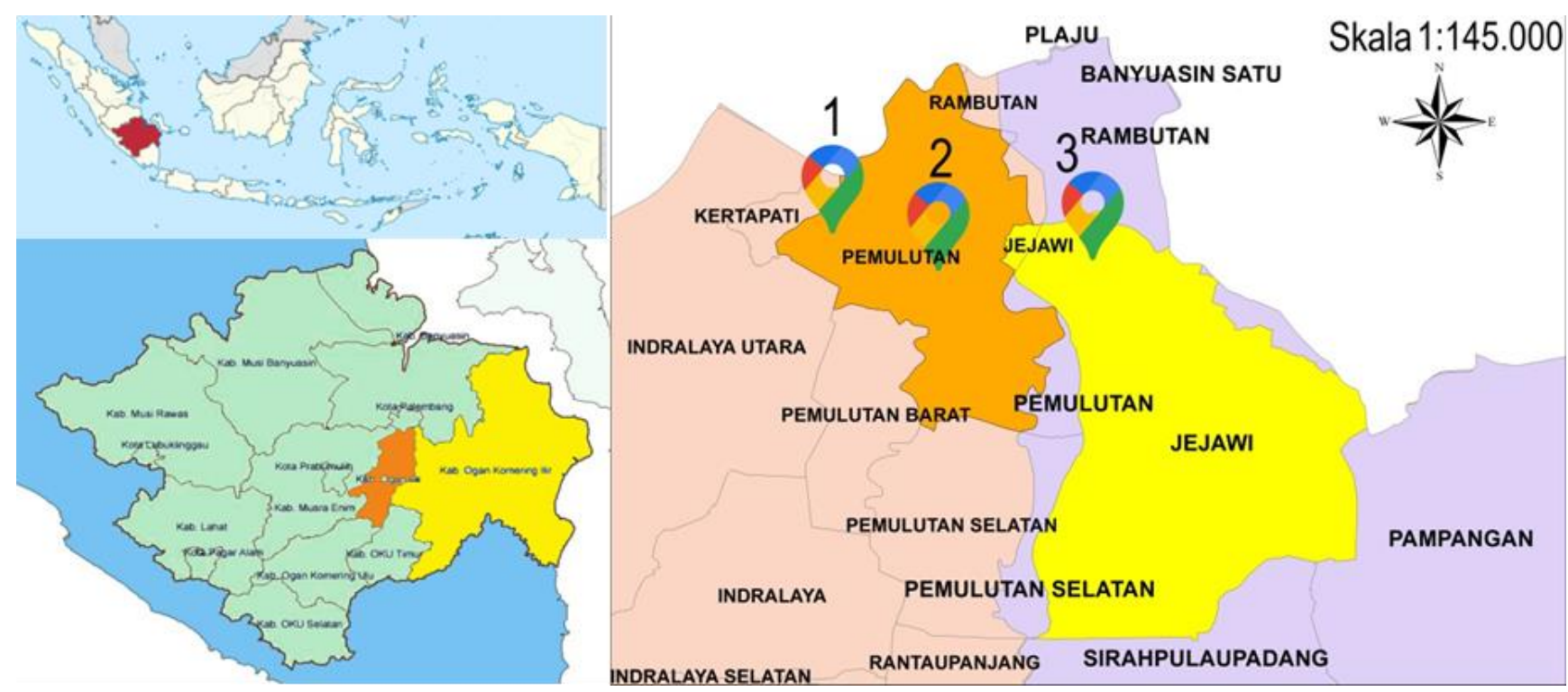

Figure 1. Locations of the survey on the three types of rice fields in freshwater swamps of South Sumatra, Indonesia. 1. PI-100, 2. PI-200, 3. PI-300 
Table 1. Characteristic of the survey locations in the rice with three different planting indexes

\begin{tabular}{|c|c|c|c|}
\hline Characteristic & Rice PI-100 & Rice PI-200 & Rice PI-300 \\
\hline Village & "Pelabuhan Dalam" & "Simpang Pelabuhan Dalam" & "Pedu" \\
\hline Ordinate & ${\mathrm{E} 03^{\circ} 6.786}^{\circ} \mathrm{S} 104^{\circ} 45.504^{\prime}$ & E03ㄷ.972'S104 $44.064^{\prime}$ & $\mathrm{E} 03^{\circ} 4.936^{\prime} \mathrm{S} 104^{\circ} 48.262^{\prime}$ \\
\hline Area overlay & \pm 800 ha & \pm 300 ha & \pm 200 ha \\
\hline Planting method & $\begin{array}{l}\text { Transplanting (row } \\
\text { spacing of } 25 \times 25 \mathrm{~cm}^{2} \text { ) }\end{array}$ & $\begin{array}{l}\text { Broadcast seeding (without row } \\
\text { spacing) }\end{array}$ & $\begin{array}{l}\text { Broadcast seeding (without row } \\
\text { spacing) }\end{array}$ \\
\hline Planting period & May to August & $\begin{array}{l}\text { April to August and October to } \\
\text { January }\end{array}$ & $\begin{array}{l}\text { February to May, June to } \\
\text { September, and October to January }\end{array}$ \\
\hline Rice variety & Ciherang & Ciherang & Inpara \\
\hline Seed dosage & $25 \mathrm{~kg} \mathrm{ha}^{-1}$ & $50 \mathrm{~kg} \mathrm{ha}^{-1}$ & 60 to $80 \mathrm{~kg} \mathrm{ha}^{-1}$ \\
\hline Seed treatments & Without seed treatments & Fipronil and tebuconazole & Fipronil \\
\hline Pesticides used & Without pesticides & $\begin{array}{l}\text { Tiametoksam (insecticide), } \\
\text { Propikonazol (fungicide), and } \\
\text { Fenoksaprop-p-etil and } \\
\text { Etoksisulfuron (herbicide) }\end{array}$ & $\begin{array}{l}\text { Dimehipo and Abamectin } \\
\text { (insecticide) and Propinep } \\
\text { (fungicide) }\end{array}$ \\
\hline Water management & Depending on water river & Pompanization & Pompanization \\
\hline
\end{tabular}

Note: Rice PI-100 = a rice planting index, Rice PI-200 = two rice planting indexes, Rice PI-300 = three rice planting indexes

\section{Observation of soil-dwelling arthropods}

The soil-dwelling arthropods were sampled every two weeks, starting from the rice aged 14 to 84 DAT. The location of the rice fields for sampling the soil-dwelling arthropods was the same as that of sampling the arboreal arthropods. The tool for sampling the soil-dwelling arthropods used pitfall traps following the method of Herlinda et al. (2018) consisting of a plastic cup $(\varnothing=9.5$ $\mathrm{cm}$, height $=12 \mathrm{~cm}$ ) filled with up to one-third of the detergent solution to trap the arthropods. The traps were placed on the side of the bund and parallel to the ground The traps were installed for 1 x 24 hours in good weather conditions without rain. The arthropods obtained were put into $10 \mathrm{~mL}$ volume vials containing $96 \%$ ethanol and labeled for further identification.

\section{Data analysis}

The data on the number of individuals or the abundance of each species of arthropods from each land type (PI-100, PI-200, and PI-300) were used to analyze the abundance and species diversity. The species diversity was analyzed using the Shannon-Wiener index $\left(\mathrm{H}^{\prime}\right)$, dominance (D), and Evenness (E) using a guidebook of Magurran (1988). The grouping data were based on guilds, namely the predatory arthropods (spiders and predatory insects), parasitoids, herbivorous insects, and neutral insects displayed in graphs or tables.

\section{RESULTS AND DISCUSSION}

\section{The abundance of arthropods in three different rice planting indexes}

The species number of arboreal and soil-dwelling predatory arthropods found in freshwater swamps in South Sumatra was 59 species (Table 2 and Figure 2). The species found belonged to the class of Arachnida and Insecta. From the class of Arachnida, there were eight families, while from the class of Insecta, there were 11 families. The predatory arthropod species were found in three survey locations, including Pardosa pseudoannulata,
Tetragnatha javana, Tetragnatha virescens, Pheropsophus occipitalis, Micraspis lineata, and Paederus fuscipes. The abundance of the arboreal predatory arthropods in PI-300 was the highest (155 individuals/60 D-vac.), whereas that in PI-100 (75 individuals/60 D-vac.) was the lowest. In contrast, the abundance of soil-dwelling predatory arthropods was the highest in PI-100 compared to that of arthropods in PI-300 and PI-200. Therefore, the rice PI-300 was the most ideal habitats and niches to maintain the abundance and diversity of species of the arboreal predatory arthropods, while the rice PI-100 was the most ideal for habitats and niches of the soil-dwelling predatory arthropods. The rice cultivation throughout the year is profitable in maintaining and conserving the abundance and species diversity of the predatory arthropods.

The parasitoids were mostly found in the canopy of rice (12 species), only one species was found on the ground (Pteromalus sp.) (Table 3). The parasitoids found came from 9 families. The dominant species of the parasitoids were found in the three survey locations, including Cardiochiles sp., Ichneutes sp., Copidosoma sp., Acantholyda sp., and Pteromalus sp. The abundance of the parasitoid was the highest (16 individuals/60 D-vac.) in the PI-100, then followed by the abundance in the PI-300 (7 individuals/60 D-vac.) and the PI-200 (3 individuals/60 Dvac.).

The species number of herbivorous insects found in the rice canopy and soil surface was 23 species (Table 4). The species found came from 16 families, and the dominant species in all locations were Orseolia oryzae, Leptocorisa acuta, Cofana spectra, Nilavarpata lugens, and Sogatella furcifera. The abundance of the herbivorous insects inhabiting the crown and soil surface was the highest at PI100, followed by that at PI-300 and PI-200.

The species number of neutral insects (pollinators and decomposers) found in the rice canopy and soil surface was 6 species, namely Calliphora sp., Chironomus sp., Heleomyza sp., Heleomyza sp., Lonchoptera sp., Musca sp., and Tipula maxima (Table 5). The abundance of neutral insects in the crown and soil surface was the highest at PI-300, while the lowest was in PI-100. 
Table 2. The abundance of arboreal and soil-dwelling predatory arthropods in the rice with three different planting indexes

\begin{tabular}{|c|c|c|c|c|c|c|}
\hline \multirow{3}{*}{$\begin{array}{l}\text { Ordo/Family/ } \\
\text { Species }\end{array}$} & \multicolumn{6}{|c|}{$\begin{array}{l}\text { The abundance of arboreal } \\
\text { (individual/60 D-vac.) and soil- } \\
\text { dwelling (individual/60 pitfall } \\
\text { traps) predatory arthropods }\end{array}$} \\
\hline & \multicolumn{2}{|c|}{$\begin{array}{c}\text { Rice } \\
\text { PI-100 }\end{array}$} & \multicolumn{2}{|c|}{$\begin{array}{c}\text { Rice } \\
\text { PI-200 }\end{array}$} & \multicolumn{2}{|c|}{$\begin{array}{c}\text { Rice } \\
\text { PI-300 }\end{array}$} \\
\hline & 串 & 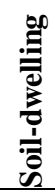 & 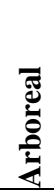 & & 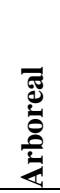 & مُ \\
\hline \multicolumn{7}{|l|}{ Araneae } \\
\hline \multicolumn{7}{|l|}{ Araneidae } \\
\hline Araneus inustus & 1 & 0 & 0 & 0 & 1 & 0 \\
\hline Argiope catenulata & 0 & 0 & 0 & 0 & 2 & 0 \\
\hline Cyclosa sp. & 0 & 0 & 1 & 0 & 1 & 0 \\
\hline Neoscona theisi & 0 & 0 & 1 & 0 & 0 & 0 \\
\hline Araneus sp. & 2 & 0 & 1 & 0 & 0 & 0 \\
\hline \multicolumn{7}{|l|}{ Lycosidae } \\
\hline Hogna rizali & 0 & 0 & 0 & 1 & 0 & 0 \\
\hline Pardosa birmanica & 0 & 0 & 0 & 3 & 0 & 3 \\
\hline Pardosa pseudoannulata & 0 & 17 & 5 & 6 & 3 & 18 \\
\hline Pardosa sumatrana & 0 & 0 & 0 & 0 & 0 & 1 \\
\hline Pardosa sacayi & 0 & 0 & 0 & 0 & 0 & 1 \\
\hline Lycosa sp. & 1 & 0 & 0 & 0 & 0 & 0 \\
\hline \multicolumn{7}{|l|}{ Linyphiidae } \\
\hline Atypena sp. & 1 & 0 & 0 & 0 & 1 & 0 \\
\hline Bathyphantes sp. & 0 & 0 & 1 & 0 & 1 & 0 \\
\hline Erigone sp. & 0 & 0 & 4 & 0 & 0 & 0 \\
\hline Linyphiid unidentified sp. & 11 & 0 & 4 & 0 & 1 & 0 \\
\hline \multicolumn{7}{|l|}{ Oxyopidae } \\
\hline Peucetia sp. & 0 & 0 & 0 & 0 & 1 & 0 \\
\hline Oxyopes javanus & 1 & 0 & 0 & 0 & 0 & 0 \\
\hline Oxyopes matiensis & 0 & 0 & 0 & 0 & 2 & 0 \\
\hline Oxyopes pingasus & 1 & 0 & 0 & 0 & 1 & 0 \\
\hline Oxyopes salticus & 2 & 0 & 0 & 0 & 0 & 0 \\
\hline \multicolumn{7}{|l|}{ Salticidae } \\
\hline Cosmophasis sp. & 0 & 0 & 0 & 0 & 1 & 0 \\
\hline Hyllus maskaranus & 2 & 0 & 1 & 0 & 0 & 0 \\
\hline Flexipus sp. & 1 & 0 & 0 & 0 & 0 & 0 \\
\hline Salticid & 0 & 0 & 1 & 0 & 1 & 0 \\
\hline \multicolumn{7}{|l|}{ Tetragnathidae } \\
\hline Tetragnatha javana & 5 & 0 & 10 & 0 & 11 & 0 \\
\hline Tetragnatha virescens & 17 & 0 & 32 & 0 & 7 & 0 \\
\hline Tetragnatha vermiformis & 1 & 0 & 6 & 0 & 0 & 0 \\
\hline Tetragnatha maxillosa & 2 & 0 & 3 & 0 & 0 & 0 \\
\hline Tetragnatha mandibulata & 0 & 0 & 1 & 0 & 0 & 0 \\
\hline Dyschiriognatha hawigtenera & 0 & 0 & 1 & 0 & 0 & 0 \\
\hline Tetragnatha sp. & 0 & 0 & 2 & 0 & 0 & 0 \\
\hline
\end{tabular}

\begin{tabular}{|c|c|c|c|c|c|c|}
\hline \multicolumn{7}{|l|}{ Theridiidae } \\
\hline $\begin{array}{l}\text { Enoplognatha sp. } \\
\text { Thomisidae }\end{array}$ & 0 & 0 & 1 & 0 & 1 & 0 \\
\hline Thomisus sp. & 2 & 0 & 1 & 0 & 0 & 0 \\
\hline \multicolumn{7}{|l|}{ Coleoptera } \\
\hline \multicolumn{7}{|l|}{ Anthicidae } \\
\hline Formicomus sp. & 1 & 0 & 0 & 0 & 1 & 0 \\
\hline \multicolumn{7}{|l|}{ Carabidae } \\
\hline Chlaenius circumdatus & 0 & 4 & 0 & 1 & 0 & 2 \\
\hline Chlaenius hamifer & 0 & 0 & 0 & 0 & 0 & 2 \\
\hline Clivina sp. & 0 & 1 & 0 & 0 & 0 & 3 \\
\hline Lesticus sp. & 0 & 0 & 0 & 0 & 0 & 4 \\
\hline Ophionea nigrofasciata & 0 & 0 & 0 & 0 & 1 & 0 \\
\hline Pheropsophus occipitalis & 0 & 47 & 0 & 25 & 0 & 27 \\
\hline Pheropsophus javanus & 0 & 8 & 0 & 0 & 0 & 3 \\
\hline Pheropsophus sp. & 0 & 1 & 0 & 0 & 0 & 0 \\
\hline \multicolumn{7}{|l|}{ Coccinellidae } \\
\hline Micraspis lineata & 2 & 0 & 6 & 0 & 41 & 0 \\
\hline Micraspis inops & 2 & 0 & 6 & 0 & 4 & 0 \\
\hline Coccinella repanda & 1 & 0 & 0 & 0 & 1 & 0 \\
\hline Coccinella sp. & 9 & 0 & 1 & 0 & 8 & 0 \\
\hline \multicolumn{7}{|l|}{ Staphylinidae } \\
\hline Paederus fuscipes & 3 & 5 & 10 & 1 & 14 & 1 \\
\hline \multicolumn{7}{|l|}{ Diptera } \\
\hline \multicolumn{7}{|l|}{ Chamaemyiidae } \\
\hline Chamaemyia sp. & 0 & 0 & 2 & 1 & 1 & 3 \\
\hline \multicolumn{7}{|l|}{ Hemiptera } \\
\hline \multicolumn{7}{|l|}{ Gerridae } \\
\hline Gerris sp. & 0 & 0 & 0 & 0 & 0 & 1 \\
\hline \multicolumn{7}{|l|}{ Miridae } \\
\hline Cyrtorhinus lividipennis & 5 & 0 & 2 & 0 & 0 & 0 \\
\hline \multicolumn{7}{|c|}{ Nepidae } \\
\hline Ranatra linearis & 0 & 0 & 0 & 0 & 0 & 4 \\
\hline \multicolumn{7}{|l|}{ Hymenoptera } \\
\hline \multicolumn{7}{|l|}{ Formicidae } \\
\hline Lasius sp. & 0 & 0 & 0 & 0 & 2 & 0 \\
\hline Odontoponera transversa & 2 & 0 & 0 & 0 & 3 & 1 \\
\hline Solenopsis sp. & 0 & 2 & 0 & 2 & 1 & 4 \\
\hline
\end{tabular}

Odonata

Coenagrionidae

$\begin{array}{lllllcl}\text { Agriocnemis } \text { sp. } & 0 & 0 & 1 & 0 & 32 & 0 \\ \text { Agriocnemis clauseni } & 0 & 0 & 0 & 0 & 2 & 0\end{array}$

$\begin{array}{lllllll}\text { Ceriagrion glabrum } & 0 & 0 & 1 & 0 & 6 & 0\end{array}$

$\begin{array}{lllllll}\text { Coenagrion sp. } & 0 & 0 & 0 & 0 & 2 & 0\end{array}$

Libellulidae

$\begin{array}{ccccccc}\text { Libellula } \text { sp. } & 0 & 0 & 0 & 3 & 1 & 0 \\ \text { Total abundance } & 75 & 85 & 105 & 43 & 155 & 78\end{array}$

$\begin{array}{lllllll}\text { Species number } & 23 & 8 & 26 & 9 & 31 & 16\end{array}$

Note: Rice PI-100 $=$ a rice planting index, Rice PI-200 $=$ two rice planting indexes, Rice PI-300 = three rice planting indexes 


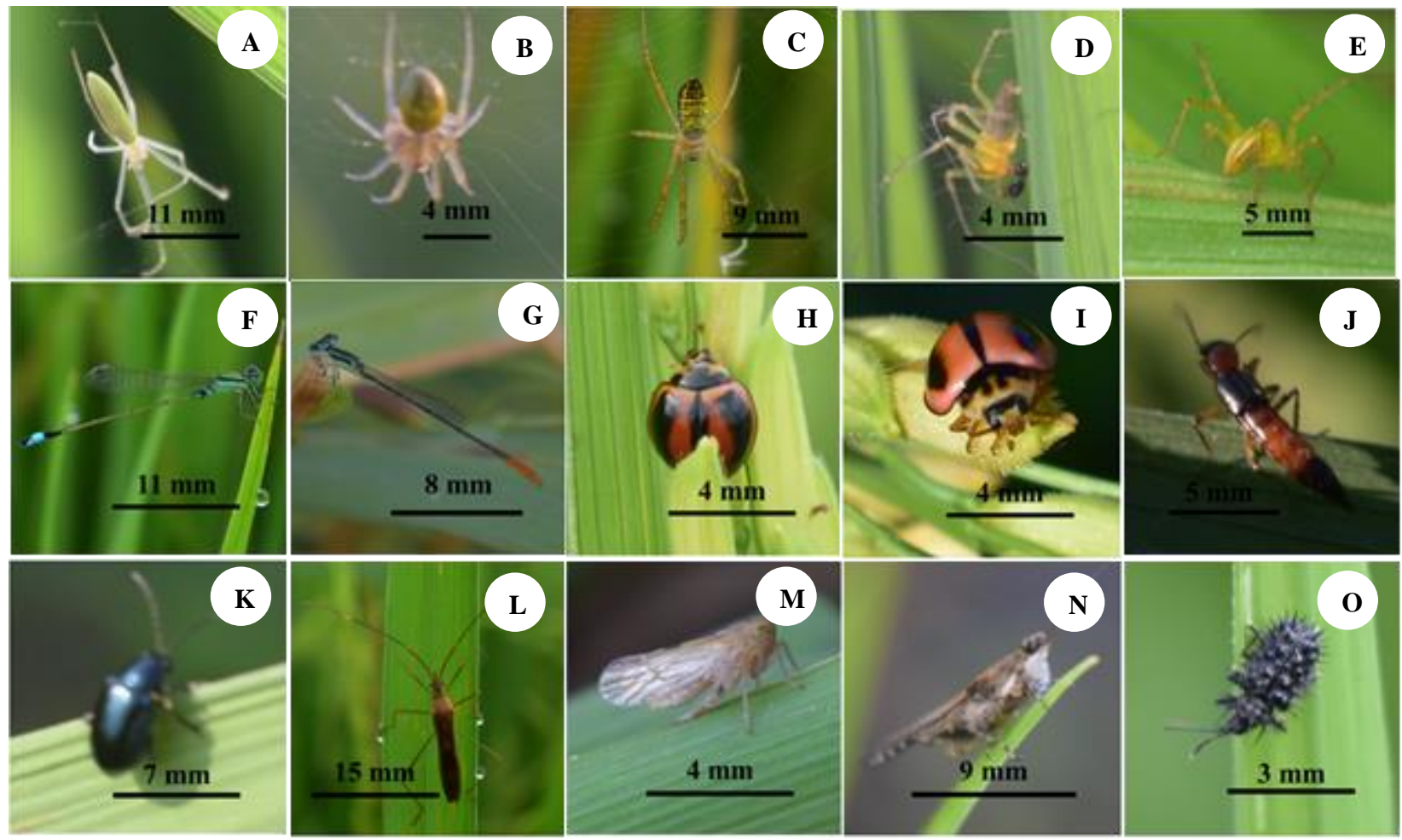

Figure 2. Dominant arthropod species found in the rice fields during a rice season: Tetragnathidae (A), Araneidae (B), Argiope catenulate (C), Oxyopes salticus (D), Oxyopes matiensis (E), Agriocnemis clauseni (F), Agriocnemis sp. (G), Micraspis inops (H), Micraspis lineata (I), Paederus sp. (J), Chrysolina coerulans (K), Leptocorisa acuta (L), Nilavarpata lugens (M), Tetrix subulata (N), Hispa atra $(\mathrm{O})$
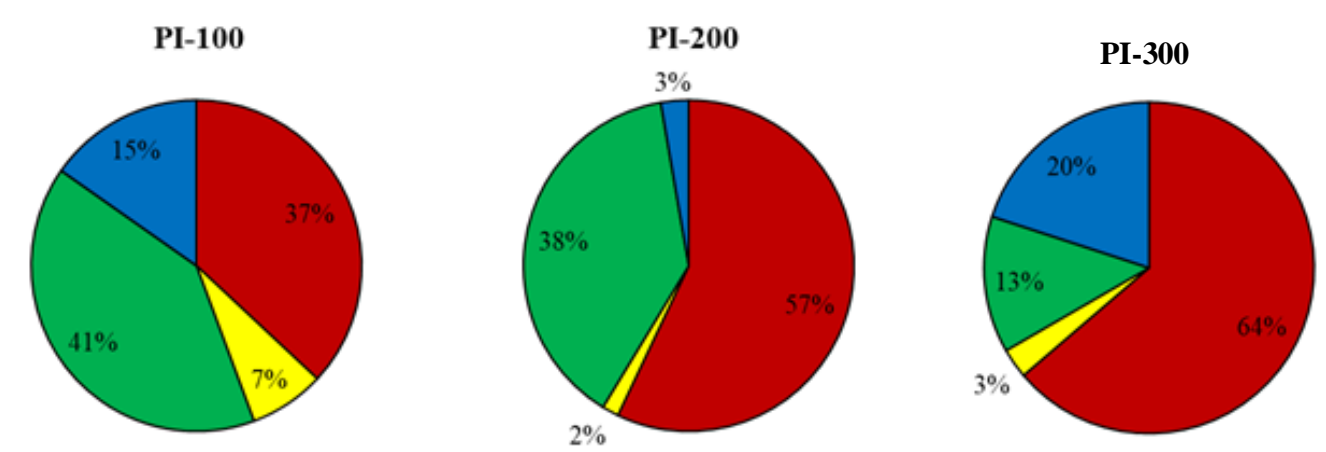

- Predatory arthropods

口Parasitoids

口Herbivorous insects

Neutral insects

Figure 3. The proportion of the arboreal arthropod guilds found in the rice with three different planting indexes
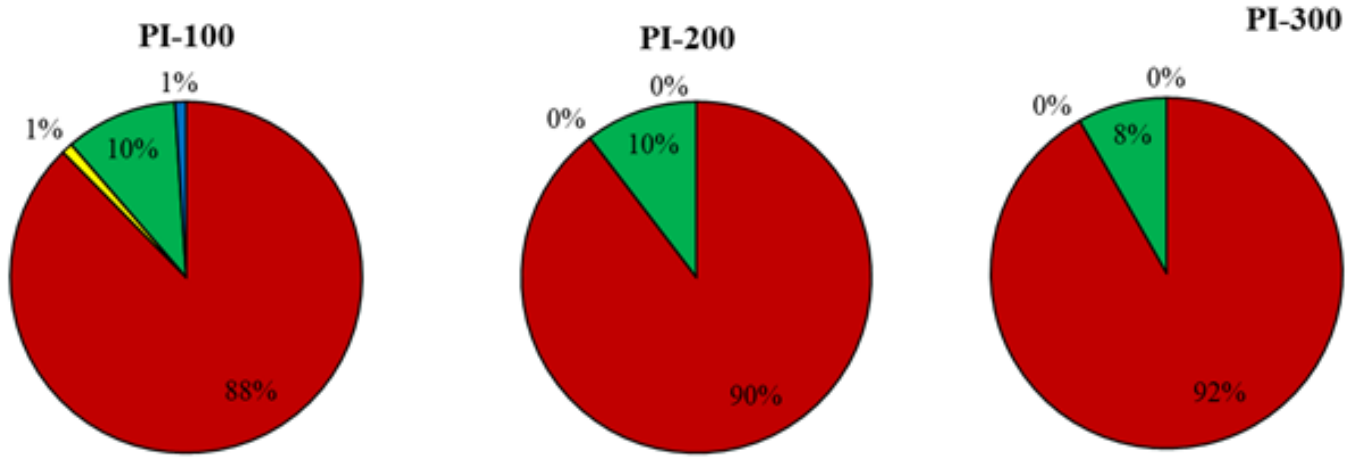

QPredatory arthropods

aParasitoids

aHerbivorous insects

aNeutral insects

Figure 4. The proportion of the soil-dwelling arthropod guilds found in the rice with three different planting indexes 
Table 3. The abundance of parasitoids in the rice with three different planting indexes

\begin{tabular}{|c|c|c|c|c|c|c|}
\hline \multirow{3}{*}{$\begin{array}{l}\text { Ordo/Family/ } \\
\text { Species }\end{array}$} & \multicolumn{6}{|c|}{$\begin{array}{c}\text { The abundance of arboreal } \\
\text { (individual/60 D-vac.) and soil- } \\
\text { dwelling (individual/60 pitfall } \\
\text { traps) parasitoid }\end{array}$} \\
\hline & \multicolumn{2}{|c|}{$\begin{array}{c}\text { Rice } \\
\text { PI-100 }\end{array}$} & \multicolumn{2}{|c|}{$\begin{array}{c}\text { Rice } \\
\text { PI-200 }\end{array}$} & \multicolumn{2}{|c|}{$\begin{array}{c}\text { Rice } \\
\text { PI-300 }\end{array}$} \\
\hline & 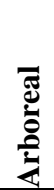 & 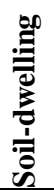 & 焉 & 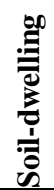 & 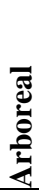 & $\frac{0}{0}$ \\
\hline \multicolumn{7}{|l|}{ HYMENOPTERA } \\
\hline Aulacidae & & & & & & \\
\hline $\begin{array}{l}\text { Pristaulacus sp. } \\
\text { Braconidae }\end{array}$ & 0 & 0 & 0 & 0 & 2 & 0 \\
\hline Cardiochiles sp. & 3 & 0 & 0 & 0 & 0 & 0 \\
\hline $\begin{array}{l}\text { Ichneutes sp. } \\
\text { Ceraphronidae }\end{array}$ & 4 & 0 & 0 & 0 & 2 & 0 \\
\hline $\begin{array}{l}\text { Ceraphron sp. } \\
\text { Encyrtidae }\end{array}$ & 1 & 0 & 1 & 0 & 0 & 0 \\
\hline $\begin{array}{l}\text { Copidosoma sp. } \\
\text { Eulophidae }\end{array}$ & 4 & 0 & 0 & 0 & 0 & 0 \\
\hline $\begin{array}{l}\text { Elasmus curticornis } \\
\text { Eurytomidae }\end{array}$ & 0 & 0 & 1 & 0 & 0 & 0 \\
\hline $\begin{array}{l}\text { Tetramesa } \mathrm{sp} . \\
\text { Mymaridae }\end{array}$ & 0 & 0 & 0 & 0 & 1 & 0 \\
\hline $\begin{array}{l}\text { Gonatocerus sp. } \\
\text { Pamphiliidae }\end{array}$ & 1 & 0 & 0 & 0 & 0 & 0 \\
\hline $\begin{array}{l}\text { Acantholyda sp. } \\
\text { Ptreromalidae }\end{array}$ & 1 & 0 & 0 & 0 & 2 & 0 \\
\hline Pteromalus sp. & 1 & 1 & 1 & 0 & 0 & 0 \\
\hline Total abundance & 15 & 1 & 3 & 0 & 7 & 0 \\
\hline Species number & 7 & 1 & 3 & 0 & 4 & 0 \\
\hline
\end{tabular}

Note: Rice PI-100 = a rice planting index, Rice PI-200 = two rice planting indexes, Rice PI-300 $=$ three rice planting indexes

On the rice canopy and soil surface, the predatory arthropods were more dominant in all locations compared to other guilds (parasitoids, herbivorous insects, and neutral insects), meanwhile (Figures 3 and 4) in the rice PI-300 canopy, the predatory arthropods dominated the habitat, while the PI-100 canopy was dominated by the herbivorous insects. In the rice PI-300, the abundance of arboreal predatory arthropods was high from the beginning of the season, whereas in the PI-100 and PI-200 rice, the abundance of arboreal predatory arthropods was lower (Figure 5). The herbivorous insects continued to dominate from the beginning of the growing season in the rice PI-100 and PI-200, but in the PI-300, the predatory arthropods were dominant. However, soil-dwelling predatory arthropods were more abundant in the rice PI-100, compared to those in the rice PI-200 and PI-300 (Figure 6).
Table 4. The population of arboreal and soil-dwelling herbivorous insects in the rice with three different planting indexes

\begin{tabular}{|c|c|c|c|c|c|c|}
\hline \multirow{3}{*}{$\begin{array}{l}\text { Ordo/Family/ } \\
\text { Species }\end{array}$} & \multicolumn{6}{|c|}{$\begin{array}{l}\text { The population of arboreal } \\
\text { (individual/60 D-vac.) and soil- } \\
\text { dwelling (individual/60 pitfall } \\
\text { traps) herbivorous insects }\end{array}$} \\
\hline & \multicolumn{2}{|c|}{$\begin{array}{c}\text { Rice } \\
\text { PI-100 }\end{array}$} & \multicolumn{2}{|c|}{$\begin{array}{c}\text { Rice } \\
\text { PI-200 }\end{array}$} & \multicolumn{2}{|c|}{$\begin{array}{c}\text { Rice } \\
\text { PI-300 } \\
\end{array}$} \\
\hline & 童 & 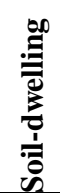 & 苞 & 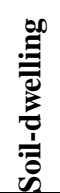 & $\frac{\bar{d}}{2}$ & 兰 \\
\hline \multicolumn{7}{|l|}{$\overline{\text { COLEOPTERA }}$} \\
\hline \multicolumn{7}{|l|}{ Chrysomelidae } \\
\hline Chrysolina coerulans & 0 & 0 & 0 & 0 & 1 & 0 \\
\hline $\begin{array}{l}\text { Hispa atra } \\
\text { Elateridae }\end{array}$ & 1 & 0 & 0 & 0 & 0 & 0 \\
\hline $\begin{array}{l}\text { Athous sp. } \\
\text { DIPTERA }\end{array}$ & 0 & 0 & 0 & 0 & 1 & 0 \\
\hline \multicolumn{7}{|l|}{ Agromyzidae } \\
\hline $\begin{array}{l}\text { Phytomyza sp. } \\
\text { Anthomyzidae }\end{array}$ & 9 & 0 & 0 & 0 & 0 & 0 \\
\hline $\begin{array}{l}\text { Anthomyza sp. } \\
\text { Cecidomyiidae }\end{array}$ & 1 & 0 & 9 & 0 & 2 & 0 \\
\hline $\begin{array}{l}\text { Orseolia sp. } \\
\text { Lonchaeidae }\end{array}$ & 7 & 0 & 50 & 0 & 10 & 0 \\
\hline $\begin{array}{l}\text { Lonchaea sp. } \\
\text { HEMIPTERA } \\
\text { Alydidae }\end{array}$ & 1 & 0 & 0 & 0 & 0 & 0 \\
\hline $\begin{array}{l}\text { Leptocorisa acuta } \\
\text { Ciccadelidae }\end{array}$ & 12 & 0 & 3 & 0 & 3 & 0 \\
\hline Nephotettix virescens & 3 & 0 & 0 & 0 & 5 & 0 \\
\hline Recilia dorsalis & 0 & 0 & 0 & 0 & 1 & 0 \\
\hline $\begin{array}{l}\text { Cofana spectra } \\
\text { Coreidae }\end{array}$ & 27 & 0 & 0 & 0 & 0 & 0 \\
\hline $\begin{array}{l}\text { Cletus trigonus } \\
\text { Delphacidae }\end{array}$ & 1 & 0 & 0 & 0 & 0 & 0 \\
\hline Nilavarpata lugens & 14 & 0 & 7 & 1 & 4 & 0 \\
\hline $\begin{array}{l}\text { Sogatella furcifera } \\
\text { LEPIDOPTERA } \\
\text { Hepialidae }\end{array}$ & 15 & 0 & 0 & 0 & 0 & 0 \\
\hline $\begin{array}{l}\text { Sthenopis sp. } \\
\text { Noctuidae }\end{array}$ & 0 & 0 & 0 & 0 & 1 & 0 \\
\hline $\begin{array}{l}\text { Spodoptera litura } \\
\text { Pyralidae }\end{array}$ & 1 & 0 & 0 & 0 & 0 & 0 \\
\hline $\begin{array}{l}\text { Cnaphalocrosis } \\
\text { medinalis }\end{array}$ & 1 & 0 & 0 & 0 & 0 & 0 \\
\hline $\begin{array}{l}\text { Scirpophaga innotata } \\
\text { ORTHOPTERA } \\
\text { Acrididae }\end{array}$ & 1 & 0 & 1 & 0 & 3 & 1 \\
\hline Oxya chinensis & 0 & 0 & 0 & 0 & 1 & 0 \\
\hline Acrida turrita & 1 & 0 & 1 & 0 & 0 & 0 \\
\hline $\begin{array}{l}\text { Valanga nigricornis } \\
\text { Grylotalpidae }\end{array}$ & 10 & 2 & 0 & 0 & 0 & 0 \\
\hline $\begin{array}{l}\text { Grylotalpa } \mathrm{sp} . \\
\text { Tetrigidae }\end{array}$ & 0 & 6 & 0 & 2 & 0 & 5 \\
\hline Tetrix subulata & 1 & 2 & 0 & 2 & 0 & 1 \\
\hline Total abundance & 106 & 10 & 71 & 5 & 32 & 7 \\
\hline Species number & 17 & 3 & 6 & 3 & 11 & 3 \\
\hline
\end{tabular}

Note: Rice PI-100 $=$ a rice planting index, Rice PI-200 $=$ two rice planting indexes, Rice PI-300 = three rice planting indexes 


\section{The species diversity of arthropods in three different rice planting indexes}

In the rice PI-300, the species number of the arboreal predatory arthropods was found the most (31 species) compared to that in the rice PI-100 (23 species) and PI-200 (26 species), but the index value of the species diversity in the rice PI-300 canopy was the lowest (2.55) compared to the index value of the rice PI-100 (2.69) and PI-200 (2.66) (Table 6). The species number of soil-dwelling predatory arthropods in the rice PI-300 was also the highest (16 species), whereas in the rice PI-100 (8 species) and PI-200 (9 species), they were lower. The diversity index value of the species of the soil-dwelling predatory arthropods in the PI-300 (2.31) was the highest compared to those in the PI100 (1.46) and PI-200 (1.61).

In the rice PI-100, the species number of the herbivorous insects found in the rice crown was the most (17 species) compared to that in the rice PI-200 (6 species) and PI-300 (11 species) (Table 6). The index value of the diversity of species of the herbivorous insects in the rice PI-100 was the highest (2.25) compared to the index value in the rice PI-200 (0.99) and PI-300 (2.07). The species number of soil-dwelling herbivorous insects in all locations was only three species. The species diversity index value of the soil-dwelling herbivorous insects in the PI-200 rice (1.05) was the highest compared to the rice PI-100 (0.80) and PI-300 (0.80).
Table 5. The abundance of arboreal and soil-dwelling neutral insects in the rice with three different planting indexes

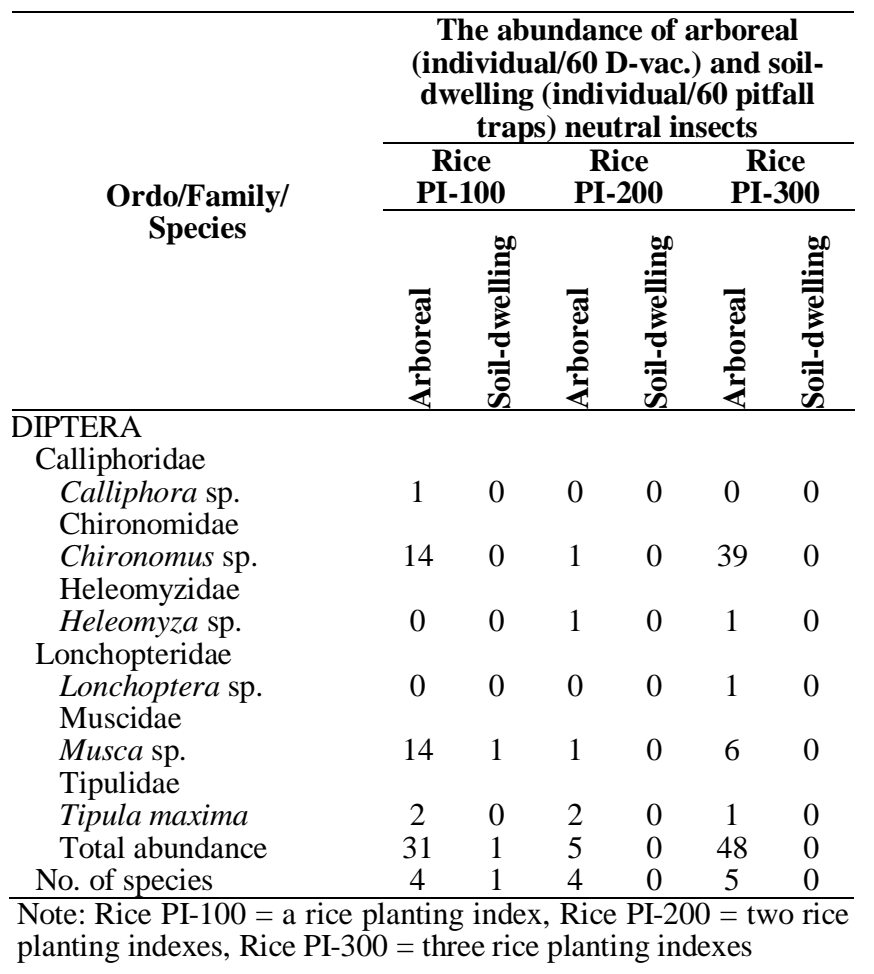

Table 6. Community characteristics of the arboreal and soil-dwelling arthropods in the rice with three different planting indexes

\begin{tabular}{|c|c|c|c|c|c|}
\hline Sampling & Guilds & Community characteristics & Rice PI-100 & $\begin{array}{c}\text { Rice PI- } \\
200 \\
\end{array}$ & $\begin{array}{c}\text { Rice PI- } \\
\mathbf{3 0 0} \\
\end{array}$ \\
\hline \multirow[t]{20}{*}{ Arboreal } & \multirow[t]{5}{*}{ Predatory arthropods } & Abundance (individual/60 D-vac.) & 75 & 105 & 155 \\
\hline & & Species number $(\mathrm{S})$ & 23 & 26 & 31 \\
\hline & & Biodiversity index (H') & 2.69 & 2.60 & 2.55 \\
\hline & & Dominance index (D) & 0.14 & 0.30 & 0.26 \\
\hline & & Evenness index (E) & 0.85 & 0.80 & 0.74 \\
\hline & \multirow{5}{*}{ Parasitoids } & Abundance (individual/60 D-vac.) & 15 & 3 & 7 \\
\hline & & Species number $(\mathrm{S})$ & 7 & 3 & 4 \\
\hline & & Biodiversity index (H') & 1.99 & 1.10 & 1.35 \\
\hline & & Dominance index (D) & 0.24 & 0.33 & 0.29 \\
\hline & & Evenness index $(\mathrm{E})$ & 0.90 & 1.00 & 0.98 \\
\hline & \multirow{5}{*}{ Herbivorous insects } & Abundance (individual/60 D-vac.) & 106 & 71 & 32 \\
\hline & & Species number $(\mathrm{S})$ & 17 & 6 & 11 \\
\hline & & Biodiversity index (H') & 2.25 & 0.99 & 2.07 \\
\hline & & Dominance index (D) & 0.25 & 0.70 & 0.31 \\
\hline & & Evenness index $(\mathrm{E})$ & 0.79 & 0.55 & 0.86 \\
\hline & \multirow[t]{5}{*}{ Neutral insects } & Abundance (individual/60 D-vac.) & 31 & 5 & 48 \\
\hline & & Species number $(\mathrm{S})$ & 4 & 4 & 5 \\
\hline & & Biodiversity index (H') & 1.03 & 1.33 & 0.67 \\
\hline & & Dominance index (D) & 0.49 & 0.40 & 0.81 \\
\hline & & Evenness index (E) & 0.74 & 0.96 & 0.42 \\
\hline \multirow{10}{*}{$\begin{array}{l}\text { Soil- } \\
\text { dwelling }\end{array}$} & \multirow[t]{5}{*}{ Predatory arthropods } & Abundance (individual/60 pitfall traps) & 85 & 43 & 78 \\
\hline & & Species number $(\mathrm{S})$ & 8 & 9 & 16 \\
\hline & & Biodiversity index (H') & 1.46 & 1.61 & 2.13 \\
\hline & & Dominance index (D) & 0.51 & 0.46 & 0.35 \\
\hline & & Evenness index $(\mathrm{E})$ & 0.70 & 0.70 & 0.77 \\
\hline & \multirow[t]{5}{*}{ Herbivorous insects } & Abundance (individual/60 pitfall traps) & 10 & 5 & 7 \\
\hline & & Species number $(\mathrm{S})$ & 3 & 3 & 3 \\
\hline & & Biodiversity index (H') & 0.80 & 1.05 & 0.80 \\
\hline & & Dominance index (D) & 0.70 & 0.40 & 0.71 \\
\hline & & Evenness index (E) & 0.73 & 0.96 & 0.72 \\
\hline
\end{tabular}

Note: Rice PI-100 = a rice planting index, Rice PI-200 = two rice planting indexes, Rice PI-300 = three rice planting indexes 

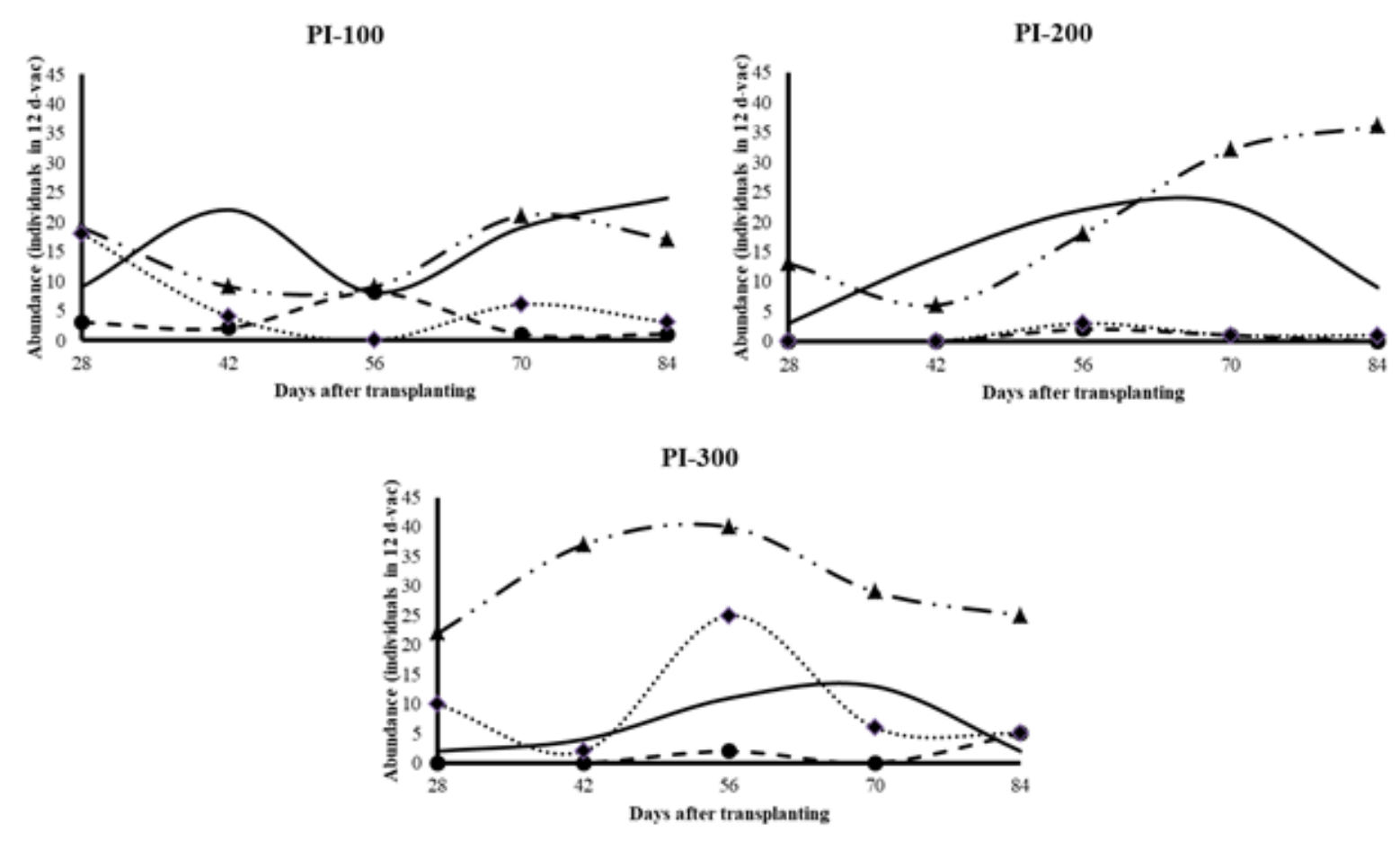

$\rightarrow$ Predatory arthropods $\quad$ ๑- Parasitoids $\longrightarrow$ Herbivorous insects $\quad \cdots \bullet \cdot$ Neutral insects

Figure 5. The abundance of the arboreal arthropod found in the rice with three different planting indexes in the period 28-84 days after transplanting
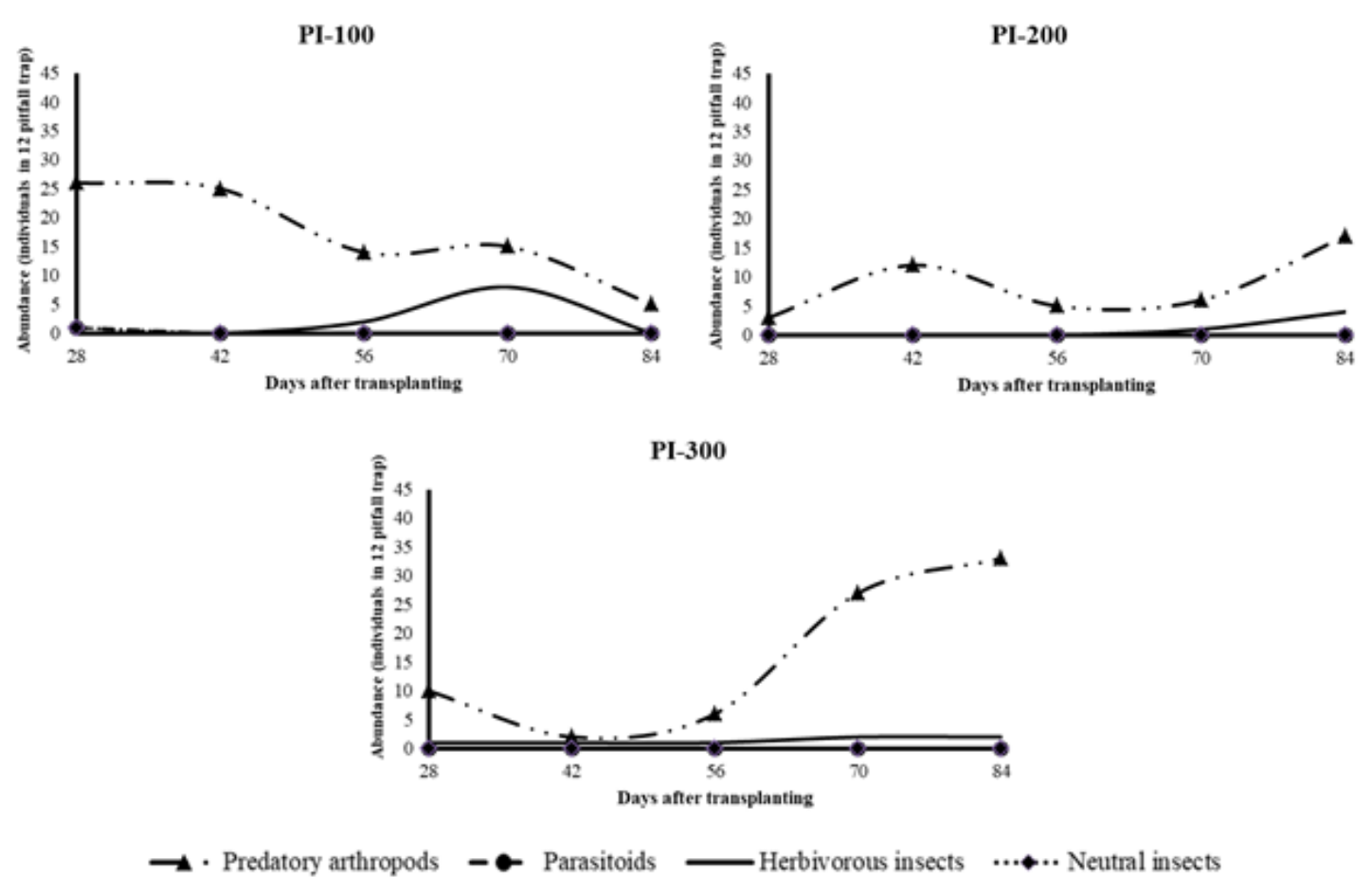

Figure 6. Abundance of the soil-dwelling arthropod found in the rice with three different planting indexes in the period 28-84 days after transplanting 


\section{Discussion}

The predatory arthropod species found in this study, including $P$. pseudoannulata, T. javana, T. virescens, $P$. occipitalis, $M$. lineata, and $P$. fuscipes, were the predators that preyed on rice insect pests. $P$. pseudoannulata, (Baehaki, 2017; Daravath and Chander 2017), T. javana (Kousika et al. 2017) and T. virescens preferred to prey on BPH (Radermacher et al. 2020), yet they also liked the neutral insects. $P$. occipitalis generally attacks rice insect pests of the order of Lepidoptera (Frank et al. 2009), Coleoptera, Homoptera, and Orthoptera (Akhil and Thomas 2018). M. lineata is a polyphagous insect pest (Jauharlina et al. 2019), but prefers BPH (Syahrawati et al. 2015). $P$. fuscipes is a predator that attacks leafhoppers (Deshwal et al. 2019). Neutral insects which were also found in the rice fields in this study were alternative prey for the generalist predatory arthropods. Settle et al. (1996) states that the generalist predatory arthropods can survive in rice fields if the herbivorous and neutral insects are available.

The abundance of the arboreal predatory arthropods in the PI-300 was the highest, and from the start of the season until just before the harvest, the abundance of arboreal predatory arthropods always exceeded the abundance of other guilds (parasitoids, herbivorous insects, and neutral insects). In contrast, the abundance of arboreal predatory arthropods in the PI-100 was the lowest. The continuous planting of rice throughout the year (PI-300) does not cause the life cycle of arthropods to be interrupted, especially the monophagous and oligophagous insects (Litsinger et al. 2011), while the polyphagous insects generally do not depend on certain plant species because they can be associated with many plant species from various families (Cano-Calle et al. 2015). The presence of arthropods throughout the years results in the continued availability of prey for the predators of rice insect pests so that the predators can breed and become abundant in the population. Prabawati et al. (2019) state that the rice planted more than once a year can provide many herbivorous insects for the prey of the generalist predatory arthropods.

In addition, the abundance of the arboreal predatory arthropods in the rice PI-300 and PI-200 was more abundant than in the rice PI-100 because, at the rice PI-300 and PI-200 locations, the rice was planted by the broadcast seeding, while in the PI-100, the rice was grown transplanting. The rice planted by broadcast seeding did not have spacing, and the population of rice clumps was more numerous and very dense. The humid and denser microclimate conditions in the rice field using the broadcast seeding are more suitable for the habitats and niches for the arboreal predatory arthropods (Kumar et al. 2018). Furthermore, Herlinda et al. (2019) point out that the abundance of the arboreal arthropods is significantly higher in the rice planted by broadcast seeding compared to those planted at more regular and sparse spacing. In this study, the spraying synthetic insecticides that occurred on the rice PI-300 and PI-200 did not appear to affect the abundance of arboreal predatory arthropods because the farmers only sprayed when the population density of insect pests was high and during the survey, they sprayed only 23 times during one planting season.

The arboreal predatory arthropods were most abundant in the rice PI-300 and dominated during one rice planting season. However, the soil-dwelling predatory arthropods were most abundant in the rice PI-100 and dominated during one rice planting season. The difference in this tendency was due to the soil-dwelling predatory arthropods having habitats in and on the soil surface. If the farmers have full soil tillage throughout the year, the habitats of soil-dwelling predatory arthropods will be disturbed, and their eggs, larvae, pupae placed on the surface or in the soil will also die. Many research results state that the full soil tillage causes the nests, habitats, and shelter for the soildwelling predatory arthropods to be disturbed (Blubaugh and Kaplan 2015; Mashavakure et al. 2019), besides that the activity of the full soil tillage can kill eggs, larvae, pupae and adults of the soil-dwelling predatory (Blubaugh and Kaplan 2015). Thus, the full soil tillage throughout the year is less beneficial for the life of the soil-dwelling arthropods. The abundance of the parasitoids was the highest in the rice PI-100 and the lowest in the rice PI-200. As for the parasitoids, the planting index did not affect their abundance. The parasitoids attacking the insect pests generally behave monophagous and oligophagous, depending on the population density of their insect hosts (Rusch et al. 2015). Fluctuation in the abundance of the parasitoids is influenced by the population density of their host or the herbivorous insects (Burks and Philpott 2017). Therefore, parasitoids have a functional response and numerical responses (Singh et al. 2017). The functional response of the parasitoids is an increase in parasitoid function by the parasitoids with an increase or decrease in the population density of their insect hosts (Burks and Philpott 2017), whereas the numerical response is the change in population density of parasitoids with changes in the population density of their insect hosts (Harbi et al. 2018). In this study, the population density of their herbivorous insect hosts was the highest in the rice PI-100. Consequently, the population density of parasitoids followed the changes in the population density of their hosts.

The dominant herbivorous insects found in this study include $O$. oryzae, L. acuta, C. spectra, N. lugens, $S$. furcifera. L. acuta and C. spectra, and N. lugens are the key rice insect pests (Zhang et al. 2013). The population of L. acuta increases in the milky stage of rice maturity because this pest sucks the milky grains of rice. $N$. lugens population is high at the beginning of the rice planting season because the brown planthopper sucks up rice stalks, especially in the vegetative phase. $N$. lugens can act as the vector of grassy stunt (Dharshini and Siddegowda 2015) and ragged stunt virus transmission (Huang 2015).

In the rice PI-300, the species number of the arboreal predatory arthropods was found the most compared to the number of species in the rice PI-100 and PI-200, but the species diversity of the arboreal predatory arthropods in the rice PI-300 was the lowest because in the rice PI-300, some species dominated, including $M$. lineata and $P$. fuscipes. 
The high species diversity of the predatory arthropods showed that the distribution of individuals in each species was more even and more balanced. The species diversity of the arboreal arthropods in rice was also determined by the vegetation structure and vegetation species around the rice field. In the rice PI-100, the wild vegetation around the rice was more diverse, and the local farmers generally cultivate the flowering vegetables on the rice fields, while in the rice PI-200 and PI-300, the fields are generally in the form of large expanses with relatively cleaner bunds. The vegetation of wild flowering plants or the flowering vegetables can increase the diversity of species of the arboreal arthropods (Herlinda et al. 2019a; Karenina et al. 2020).

The species diversity of soil-dwelling predatory arthropods in the rice PI-300 was the highest compared to that of the rice PI-100 and PI-200. In the rice PI-100 and PI-200, the species diversity of the soil-dwelling predatory arthropods was lower due to the dominance of species of $P$. occipitalis and $P$. pseudoannulata. The spraying insecticides on the surface of the soil and water can reduce the arthropod species diversity, particularly those that are sensitive can be killed (Hanif et al. 2020; Herlinda et al. 2020a). However, in this study, the intensive spraying of synthetic insecticides was not only 2-3 times during one rice planting season, even though the rice PI-200 and PI300 were applied with the synthetic insecticides, but it also did not reduce the species diversity of the soil-dwelling predatory arthropods.

The species diversity of the herbivorous insects in the rice $\mathrm{PI}-100$ was the highest compared to the index values in the rice PI-200, and PI-300 and the lowest species diversity occurred in the rice PI-200. The species diversity of the herbivorous insects in the rice PI-200 was due to the dominance of Orseolia sp. The species diversity of the herbivorous insects in the rice PI-100 had the same tendency as the species diversity of the arboreal predatory arthropods resulted from the more varied species of flora around the rice PI-100 field due to the local farmers' habit of planting bitter melon, cucumbers, long beans in the rice fields. Karenina et al. (2020) state that adaptive vegetables provide an alternative habitat and niches for herbivorous insects.

This study concludes that the abundance of arboreal predatory arthropods was the highest in the rice PI-300, and the lowest was in the rice PI-100. In contrast, the abundance of soil-dwelling predatory arthropods was the highest in the rice PI-100, and the population of the herbivorous insects was also abundant in the rice PI-100. The species number of arboreal predatory arthropods in the rice PI-300 was the highest compared to that of the rice PI100 and PI-200. The rice PI-300 was the most ideal habitats and niches to maintain the abundance and species diversity of the arboreal predatory arthropods. Therefore, the rice cultivation throughout the year is beneficial in maintaining and conserving the abundance and species diversity of the predatory arthropods.

\section{ACKNOWLEDGEMENTS}

This research was funded by the Doctoral Dissertation Research (Penelitian Disertasi Doktor) program, Directorate of Research and Community Service (DRPM), Directorate General of Research and Development, Kemenristekdikti, with the contract number: 096/SP2H/LT/DRPM/IV/2019. This research was chaired by Siti Herlinda.

\section{REFERENCES}

Akhil SV, Thomas SK. 2018. Bombardier beetles (Coleoptera: Carabidae: Brachininae) of India - notes on habit, taxonomy, and use as natural bio-control agents. In: Frontiers in Biological Research: Proceedings of the National Seminar, Department of Zoology, University of Calicut, India.

Ashrith KN, Sreenivas AG, Guruprasad GS, Hanchinal SG, Chavan I. 2017. Insect diversity: a comparative study in direct seed and transplanted rice ecosystem. J Entomol Zool Stud 5 (6): 762-765.

Baehaki SE. 2017. The Roles of predators suppress brown planthopper, Nilaparvata lugens Stal in the ricefields. Sch J Agric Vet Sci 4 (11): 452-460. DOI: 10.21276/sjavs.2017.4.11.3.

Blubaugh CK, Kaplan I. 2015. Tillage compromises weed seed predator activity across developmental stages. Biol Control 81: 76-82. DOI: 10.1016/j.biocontrol.2014.11.007.

Burks JM, Philpott SM. 2017. Community and ecosystem ecology local and landscape drivers of parasitoid abundance, richness, and composition in Urban Gardens. Community Ecosyst Ecol 46 (2): 201209. DOI: $10.1093 /$ ee/nvw175.

Cano-Calle D, Arango-Isaza RE, Saldamando-Benjumea CI. 2015. Molecular identification of Spodoptera frugiperda (Lepidoptera: Noctuidae) corn and rice strains in Colombia by using a PCR-RFLP of the Mitochondrial Gene Cytochrome Oxidase I (COI) and a PCR of the Gene FR (for rice). Ann Entomol Soc Am 108 (2): 172-180. DOI: 10.1093/aesa/sav001.

Daravath V, Chander S. 2017. Niche regulation between brown planthopper (BPH) and white-backed planthopper (WBPH) in association with their natural enemy population in the rice ecosystem. J Entomol Zool Stud 5 (5): 513-517.

Deshwal R, Sachan SK, Singh G, Singh DV, Singh G, Chand P. 2019. Seasonal abundance of insect pests associated with paddy crops in western plain zone of Uttar Pradesh. J Entomol Zool Stud 7 (3): 13471350 .

Dharshini GM, Siddegowda K. 2015. Reaction of rice landraces against brown planthopper Nilaparvata lugens Stal. Ecoscan 9 (1\&2): 605609.

Dionisio AC, Rath S. 2016. Chemosphere abamectin in soils: Analytical methods, kinetics, sorption and dissipation. Chemosphere 151: 17-29. DOI: $10.1016 /$ j.chemosphere.2016.02.058

Dominik C, Seppelt R, Horgan FG, Marquez L, Settele J, Vaclavik T. 2017. Regional-scale effects override the influence of fine-scale landscape heterogeneity on rice arthropod communities. Agric Ecosyst Environ 246: 269-278. DOI: 10.1016/j.agee.2017.06.011.

Frank JH, Erwin TL, Hemenway RC. 2009. Economically beneficial ground beetles: The specialized predators Pheropsophus aequinoctialis (L.) and Stenaptinus jessoensis (Morawitz): Their laboratory behavior and descriptions of immature stages (Coleoptera, Carabidae, Brachininae). Zookeys 36: 1-36. DOI: 10.3897/zookeys.14.188.

Hanif KI, Herlinda S, Irsan C, Pujiastuti Y. 2020. The impact of bioinsecticide overdoses of Beauveria bassiana on species diversity and abundance of not targeted arthropods in South Sumatra (Indonesia) freshwater swamp paddy. Biodiversitas 21 (5): 21242136. DOI: 10.13057/biodiv/d210541.

Harbi A, Beitia F, Ferrara F, Chermiti B, Sabater-muñoz B. 2018. Functional response of Diachasmimorpha longicaudata (Ashmead) over Ceratitis capitata (Wiedemann): influence of temperature, fruit location and host density. Crop Prot 109: 115-122. DOI: 10.1016/j.cropro.2018.03.010. 
Heinrichs EA, Nwilene FE, Stout MJ, Hadi BAR, Freita T. 2016. Rice insect pests and their management. Burleigh Dodds Science Publishing, London.

Herlinda S, Alesia M, Irsan C, Hasbi, Suparman, Anggraini E, Arsi. 2020a. Impact of mycoinsecticides and abamectin applications on species diversity and abundance of aquatic insects in rice fields of freshwater swamps of South Sumatra, Indonesia. Biodiversitas 21 (7): 3076-3083. DOI: 10.13057/biodiv/d210727.

Herlinda S, Karenina T, Irsan C, Pujiastuti Y. 2019a. Arthropods inhabiting flowering non-crop plants and adaptive vegetables planted around paddy fields of freshwater swamps of South Sumatra, Indonesia. Biodiversitas 20 (11): 3328-3339. DOI: 10.13057/biodiv/d201128.

Herlinda S, Prabawati G, Pujiastuti Y, Susilawati, Karenina T, Hasbi, Irsan C. 2020b. Herbivore insects and predatory arthropods in freshwater swamp rice field in South Sumatra, Indonesia sprayed with bioinsecticides of entomopathogenic fungi and abamectin. Biodiversitas 21 (8): 3755-3768. DOI: 10.13057/biodiv/d21083.

Herlinda S, Yudha S, Khodijah TR, Suwandi, Lakitan B, Verawaty M. 2018. Species richness and abundance of spiders inhabiting rice in fresh swamps and tidal lowlands in South Sumatra, Indonesia. J ISSAAS 24 (1): 82-93.

Herlinda S, Yusticia SR, Irsan C, Hadi BAR, Lakitan B, Verawaty M, Hasbi. 2019b. Abundance of arthropods inhabiting canopy of rice cultivated using different planting methods and varieties. J Biopest 12 (1): 7-18.

Huang HJ, Bao YY, Lao SH, Huang XH, Ye YZ, Wu JX, Xun HJ, Zhou XP, Zhang CX. 2015. Rice ragged stunt virus-induced apoptosis affects virus transmission from its insect vector, the brown planthopper to the rice plant. Sci Rep. DOI: 10.1038/srep11413.

Jauharlina J, Hasnah H, Taufik MI. 2019. Diversity and community structure of arthropods on rice ecosystem in Aceh. Agrivita J Agric Sci 1: 316-324. DOI: 10.17503/agrivita.v41i2.2160.

Kawanishi M, Mimura N. 2013. Rice farmers' response to climate and socio-economic impacts: a case study in North Sumatra, Indonesia. J Agric Meteorol 69: 9-22.

Kardol P, Long JRD. 2019. How anthropogenic shifts in plant community composition alter soil food webs [version 1; peer review: 2 approved]. F1000Research 7: 1-12. DOI: 10.12688/f1000research.13008.1.

Karenina T, Herlinda S, Irsan C, Pujiastuti Y. 2019. Abundance and species diversity of predatory arthropods inhabiting rice of refuge habitats and synthetic insecticide application in freshwater swamps in South Sumatra, Indonesia. Biodiversitas 20 (8): 2375-2387. DOI: $10.13057 /$ biodiv/d200836

Karenina T, Herlinda S, Irsan C, Pujiastuti Y. 2020. Arboreal entomophagous arthropods of rice insect pests inhabiting adaptive vegetables and refugia in freshwater swamps of South Sumatra. Agrivita J Agric Sci 42 (2): 214-228. DOI: 10.17503/agrivita.v0i0.2283.

Kousika J, Kuttalam S, Kumar MG. 2017. Evaluation on the effect of tetraniliprole $20 \mathrm{SC}$, a new chemistry of pyridine derivative to the rice arthropod biodiversity. J Entomol Zool Stud 5 (4): 133-143.

Kumar A, Ram L, Singh B. 2018. Cultivation methods impact on predators of rice pests. J Entomol Zool Stud 6 (2): 970-974.

Lakitan B, Lindiana L, Widuri LI, Kartika K, Siaga E, Meihana M. 2019. Inclusive and ecologically-sound food crop cultivation at tropical non-tidal. Agrivita 41 (1): 23-31. DOI: 10.17503/agrivita.v40i0.1717.
Lisha JM, Baskaran V, Vijay S, Vishnu M. 2020. Status of insect pests in direct-seeded and transplanted rice. J Entomol Zool Stud 8 (2): 11041107.

Litsinger JA, Barrion AT, Canapi BL, Lumaban MD, Cruz CG dela, Pantua PC. 2011. Philippine rice stemborers: a review. Philipp Ent 25 (1): $1-47$.

Magurran AE. 1988. Ecological diversity and its measurement. Chapman and Hall, London.

Margono BA, Bwangoy JRB, Potapov PV, Hansen MC. 2014. Mapping wetlands in Indonesia using Landsat and PALSAR data-sets and derived topographical indices. Geo-Spatial Inf Sci 17 (1): 60-71. DOI: 10.1080/10095020.2014.898560.

Mashavakure N, Mashingaidze AB, Musundire R, Nhamo N, Gandiwa E, Thierfelder C, Muposhi VK. 2019. Soil dwelling beetle community response to tillage, fertilizer, and weeding intensity in a sub-humid environment in Zimbabwe. Appl Soil Ecol 135: 120-128. DOI: 10.1016/j.apsoil.2018.12.001.

Masika FB, Masanza M, Aluana G, Barrigossi AF, Kizito EB. 2017. Abundance, distribution, and effects of temperature and humidity on arthropod fauna in different rice ecosystems in Uganda. J Entomol Zool Stud 5 (5): 964-973.

Prabawati G, Herlinda S, Pujiastuti Y. 2019. The abundance of canopy arthropods in South Sumatra (Indonesia) freshwater swamp main and ratooned rice applied with bioinsecticides and synthetic insecticide. Biodiversitas 20 (10): 2921-2930. DOI: 10.13057/biodiv/d201021.

Radermacher N, Hartke TR, Villareal S, Scheu S. 2020. Spiders in rice-paddy ecosystems shift from aquatic to terrestrial prey and use carbon pools of different origins. Oecologia 192: 801-812. DOI: 10.1007/s00442-020-04601-3.

Rahman MM, Thompson JR, Flower RJ, Rahman MM, Thompson JR, Flower RJ. 2020. Hydrological impacts of climate change on rice cultivated riparian wetlands in the Upper Meghna River Basin (Bangladesh and India). Hydrol Sci J 65: 33-56. DOI: 10.1080/02626667.2019.1676427.

Rusch A, Delbac L, Muneret L, Thiéry D. 2015. Organic farming and host density affect parasitism rates of tortricid moths in vineyards. Agric Ecosyst Environ 214: 46-53. DOI: 10.1016/j.agee.2015.08.019.

Settle WH, Ariawan H, Astuti ET, Cahyana W, Hakim AL, Hindayana D, Lestari AS, Pajarningsih. 1996. Managing tropical rice pests through conservation of generalist natural enemies and alternative prey. Ecology 77 (7): 1975-1988. http://www.jstor.org/stable/2265694.

Singh M, Mishra BB, Tripathi C. 2017. Effect of host's Helicoverpa armigera (Hubner) larval age on the numerical response of the parasitoid Campoletis chlorideae Uchida. J Entomol Zool Stud 5(4): 233-237.

Syahrawati M, Martono E, Putra NS, Purwanto BH. 2015. Predation and competition of two predators (Pardosa pseudoannulata and Verania lineata) on different densities of Nilaparvata lugens in laboratory. Int J Sci Res 4 (6): 610-614.

Whyte R, Anderson G. 2017. A field guide to spiders of Australia. CSIRO Publishing: Queensland.

Wood SA, Karp DS, Declerck F, Kremen C, Naeem S, Palm CA. 2015. Functional traits in agriculture: agrobiodiversity and ecosystem services. Trends Ecol Evol 20: 1-9. DOI: 10.1016/j.tree.2015.06.013.

Zhang J, Zheng X, Jian H, Qin X, Yuan F, Zhang R. 2013. Arthropod biodiversity and community structures of organic rice ecosystems in Guangdong Province, China. Florida Entomol 96: 1-9. DOI: 10.1016/j.pestbp.2015.10.003. 